\title{
The ECB Is Not Enough. A Federal Budget for the Eurozone*
}

\author{
Domènec Ruiz Devesa
}

\section{Introduction}

The long debate about completing the European monetary union with a fiscal pillar has revived since the near-collapse of the single currency in 2010-2012 as a side effect of the mostly speculative attacks on Italian, Spanish and Portuguese government bonds. Federalist authors have been engaging intensively in these discussions ${ }^{1}$, while the Eurozone budget remains a key demand of the Union of European Federalists ${ }^{2}$. Unfortunately, to this day, the Council of the European Union has not endorsed this proposal even if it has the support of all European institutions, Commission, Parliament, and even the European Central Bank.

\section{Is the ECB not enough?}

It is possible to argue that at least since 2012 the policies of the ECB have indeed guaranteed financial stability and encouraged economic growth, through a set of non-standard monetary measures such as the bond-buying program and the ultra-low interest rates. So can the ECB not just keep this policy mix in place for ever? In theory, yes, as far as the ECB continues to fail to attain its informal inflation aim of close but below $2 \%$. However, when inflation returns to "normal" levels, interest rates will rise and the purchasing of Eurozone government bonds will stop ${ }^{3}$, unless the ECB changes the current "legal base" of the bond-buying programme (transmission of monetary policy) to, for instance, maintaining financialstability.

But this will be heavily disputed by conservatives who consider that the ECB has already exceeded its mandate with the current Public Sector Purchases Programme.

Thus, in the event of economic crises affecting some Member States in a $2 \%$ inflation environment, the only reliable tool would be a common Eurozone budget with which countercyclical investments and transfers can be financed to offset sudden drops in economic activity. The crisis has shown the problems of an incomplete economic union, so the debate about the setting up of a Eurozone fiscal capacity has been back, for a while, even though already in the 1970s the McDougall Report ${ }^{4}$ called for a community budget of $5-7 \%$ of GDP in order to deal with economic shocks. More recently, the so-called Five President's report of the $22^{\text {nd }}$ June $2015^{5}$, called for the establishment of a fiscal facility for the Eurozone, while the Commission proposed it back in $2012^{6}$, and again, in May 2017, in a Reflection Paper ${ }^{7}$, and again in December 2017 with a set of draft legislative proposals on Economic and Monetary Union reform, and a policy proposal on the Euro area fiscal capacity ${ }^{8}$. Finally, the legislative proposal on a stabilisation function for the Eurozone was published in May 2018. We will review the Parliament's position first and then the different Commission's initiatives on the matter.

\section{The Commission's proposals}

The May 2017 Reflection Paper summarizes the original Commission's view on the matter $^{10}$. It offers a clear diagnosis of the situation of the euro, which is well known, i.e 
the need to complete the monetary union with the financial and fiscal pillar, and therefore proposes an agenda based mostly on the Five Presidents Report and the positions of the European Parliament. Originally, the Commission proposed a timetable for its implementation, which is fundamentally aimed at completing the banking union in this legislature, as a precondition to address the fiscal capacity of the Eurozone in the Period 2020-2025.

In the short term, that is to say until 2019, the Commission considered that the European deposit insurance should be culminated. This scheme will receive contributions from banks throughout Europe, thereby gradually replacing national funds. This will ensure equal protection of depositors irrespective of the Member State in which they reside. The Commission also intended to establish a "fiscal backstop" in order to give greater credibility to the fund for the liquidation and re-structuring of banking institutions. The current European Stability Mechanism (ESM) could perform this function through a permanent credit facility in favor of the Single Resolution Fund, which as well draws on contributions from banks. At the same time, structural reforms, through financial incentives, and improved coordination of economic policies in the euro area should continue to be pursued during this period. Finally, also before 2019, the single external representation of the euro area should be agreed upon in international financial institutions such as the IMF.

In the medium term, from 2020 to 2025, the Commission considered necessary to provide an anti-cyclical Eurozone stabilization fund vis-à-vis asymmetric macroeconomic shock. However, since the European Deposit Insurance Scheme remains blocked in the Council by the German government, the Commission has decided to move ahead with a legislative proposal on a Eurozone stabilisation function ${ }^{11}$. Initially, the fiscal capacity proposed in December 2017 included an investment fund targeted to increase the rate of growth and a European unemployment insurance to lessen the budgetary impact of the unemployment subsidy (think that in Spain at the peak of the crisis it came to an annual cost of 30 billion euros). According to the said proposal, this fiscal capacity could have been financed through the ESM, national contributions or through a fraction of taxes such as VAT or corporation tax. In the longer term it could take the form of a real permanent budget. In any case access to this financing would be conditional on meeting criteria for convergence.

However, the legislative proposal of May 2018 is limited to a mechanism to protect the level of investment during recessions, through loans and subject to having respected the fiscal and macro-economic recommendations before the crisis, for an amount of 30 billion euros. In comparison with the ESM, this appears to be past conditionality as opposed to present conditionality, i.e. policy conditions set in order to access funding. Furthermore, the interest rates of the loans are to be subsidized by annual national contributions made on the basis of the monetary income allocated to their national central banks ${ }^{12}$.

The Commission has also anticipated the legislative proposal on the pseudo European Safe Asset ${ }^{13}$, originally planned for the 20202025 period as well, in which the issuance of a "light" Eurobond was envisaged in the Reflection Paper, which would be jointly issued but not jointly guaranteed (each Member State would still be responsible for paying its proportionate share of the issue). This instrument would increase the range of financial instruments available and help diversify Bank portfolios, excessively concentrated in the public debt of the country where the financial institutions are domiciled. 


\section{Comments}

This would be the first step in issuing the Eurozone's publicly-traded public debt, under the name of European Safe Asset (ESA), a question on which there is no agreement to date. However, the German government would like to see the national public debt no longer considered riskfree, precisely in order to diversify the banks' debt acquisitions, which could only be done after a very careful analysis of its consequences and linked to the issuance of this ESA, which in a way would act as a riskfree federal bond. The Commission is quite right in linking both issues. The status of sovereign debt must not be reduced unless a European debt bond that is legally riskfree and comparable to the federal bonds issued by the US Treasury is introduced at the same time. From the governance's point of view, the Commissioner for Economic and Monetary Affairs would have to be the Eurozone Finance Minister, responsible to the European Parliament, and also President of the Eurogroup, so as to ensure full democratic legitimacy of budgetary decisions. Once integrated into the treaties, the ESM could operate as the European treasury, with the capacity to raise fiscal resources and issue Eurobonds ${ }^{14}$.

\section{Conclusions}

The Commission Reflection Paper of May 2017 was quite ambitious on the matter of the Eurozone budget, but the actual Commission's proposal tabled in May 2018 is rather disappointing since instead of proposing a real budget or fiscal capacity, another loan-based mechanism is envisaged, albeit with fully subsidized interest rates. Still there is hope that the French and German governments are ready to push for the implementation of this agenda $a^{15}$, since the German cabinet rather agrees to the Euro stabilisation function, whose cost is known, unlike the unknown liabilities of the European Deposit Insurance Scheme. In any event, from a federalist point of view, the Eurozone fiscal capacity should be endowed with new own resources of the fiscal type, in particular those coming from the Financial Transaction Tax (FTT), a CO2 tax, a share of the Common Consolidated Corporate Tax Base (whenever it is agreed in the Council), a share of the Value Added Tax (VAT) base, and an air travel tax. These fiscal resources would also allow to issue Eurozone debt, providing additional funding and a truly European safe asset.

The FTT is currently a strengthened cooperation of 10 Member States, so not all Eurozone countries are included. The Council has yet to agree to its implementtation. National authorities will be in charge of collecting the tax, which in a way makes it akin to a national contribution. It is worthwhile remembering that the European Coal and Steel Community back in 1951 already introduced the first (and so far only) supranational European tax on the production of these two commodities, which was paid directly by companies to a bank account held by the High Authority. The same system is possible with the FTT (it will be even easier, given the current technology). The original FTT proposal would have raised 30 billion euros per year (the Council may end up excluding derivatives and other financial products from the scope of the FTT, if the proposal is at all adopted).

In addition, as is the case with the U.S. Treasury, the profits from the ECB should also accrue to the proposed Eurozone treasury (in average, 1 billion euros per year). On this last item, the Commission's proposal moves in the right direction, by tapping into this resource in order to finance the interest rate of the anti-cyclical loans. Finally, the Euro area governments could easily take advantage of the still ultra-low 
interest rates in order to borrow from the financial markets and set up a European Sovereign Fund, tasked with long term purchases of equity. This will reduce capital inequality and provide additional returns for the Eurozone budget. In conclusion, we European and World federalists have a lot of pushing to do in order to secure a proper Eurozone budget, the next big step in completing the Economic and Monetary Union in a federal direction.

* This article is based on two presentations delivered at the $34^{\text {th }}$ and $35^{\text {th }}$ International Seminars on Federalism in Europe and the World held in the Island of Ventotene on the $6^{\text {th }}$ of September 2017 and the $5^{\text {th }}$ of September 2018.

\footnotetext{
${ }^{1}$ See among others Moro (2015), García and Vacca (2016) and Ruiz Devesa (2015), and (2016).

${ }^{2}$ See the among others resolutions, Union of European Federalists (2017): http://www.federalists.eu/uef/news/resolution-on-fiscal-union/,(2016): http://www. federalists.eu/uef/news/general-policy-resolution/ and (2015): http://www.federalists.eu/uef/news/resolution-of-the-uef-federal-committee-on-a-genuinemonetary-union-in-a-reforme/

${ }^{3}$ Indeed the ECB has already announced the end of this programme as of 31st December 2018. See the monetary policy decisions of 14 June 2018: https://www. ecb.europa.eu/press/pr/date/2018/html/ecb.mp180614.en.html

${ }^{4}$ See Commission of the European Communities (1977): https://www.cvce.eu/content/publication/2012/5/31/c475e949-ed28-490b-81ae-a33ce9860d09/ publishable_en.pdf

${ }_{5}^{5}$ See European Union (2015): https://ec.europa.eu/commission/sites/beta-political/files/5-presidents-report_en.pdf

${ }^{6}$ See European Commission (2012): http://ec.europa.eu/archives/commission 2010-2014/president/news/archives/2012/11/pdf/blueprint en.pdf

${ }^{7}$ See European Commission (May 2017): https://ec.europa.eu/commission/sites/beta-political/files/reflection-paper-emu_en.pdf

${ }^{8}$ See the full policy package tabled by the European Commission (December 2017): https://eur-lex.europa.eu/legal-content/EN/TXT/

PDF/?uri=CELEX:52017DC0821\&from $=$ EN

${ }^{9}$ See European Commission (2018): See European Commission (2018): https://ec.europa.eu/commission/sites/beta-political/files/budget-may2018-investmentstabilisation-function-regulation_en.pdf

${ }^{10}$ See https://ec.europa.eu/commission/sites/beta-political/files/reflection-paper-emu_en.pdf

${ }^{11}$ Thelegislative proposal was published on the31stMay 2018; seeEuropeanCommission(31stMay 2018): https://ec.europa.eu/commission/sites/beta-political/ files/budget-may2018-investment-stabilisation-function-regulation_en.pdf

${ }^{12}$ See European Commission(31st May 2018), p.3:"The proposed Regulation is accompanied by a draft intergovernmental agreement for Member States to agree among themselves on the transfer of national contributions calculated on the basis of the share of monetary income allocated to their national central banks to the StabilisationSupportFund established under the Regulation. The main purpose of this Fund, to beendowed with national contributions, is to finance the interest rate subsidies Member States are entitled to. Such interest rate subsidies cover 100 percent of the interest cost incurred on the loans".

${ }^{13}$ The legislative proposal was published on the 24 May 2018; see European Commission (24th May 2018): https://ec.europa.eu/info/law/better-regulation/ initiatives/com-2018-339_en

${ }^{14}$ These two proposals were included both in the May 2017 Reflection Paper and the legislative proposals of December 2018

${ }^{15}$ See Publius, European Letter (2017): http://www.europeanletter.eu/site/
} 